Bangladesh J. Plant Taxon. 21(2): 153-157, 2014 (December)

(C) 2014 Bangladesh Association of Plant Taxonomists

\title{
A NEW SPECIES OF ARUNDINELLA RADDI (POACEAE) FROM THE WESTERN GHATS, INDIA
}

\author{
C. N. Sunil, M. K. Ratheesh Narayanan ${ }^{1}$, Prajeesh Parameswaran ${ }^{2}$, M. Sivadasan ${ }^{3,4}$ \\ and A. H. Alfarhan ${ }^{3}$ \\ Department of Botany, S.N.M. College, Maliankara P.O., Ernakulam-683 516, Kerala, India
}

Keywords: Arundinella thirunelliensis; New species; India; Kerala; Wayanad; Western Ghats.

\begin{abstract}
Arundinella thirunelliensis (Poaceae), a new species from the Western Ghats in Kerala, India is described and illustrated. It closely resembles A. nepalensis but differs by being a rheophyte with large culms, glabrous culm nodes, leaf sheath and peduncles, effuse panicles with highly branched drooping branches, large, 3-nerved, deeply bifid smooth lemma with short twisted column of awn, and the lower glume distinctly shorter than the lower lemma.
\end{abstract}

\section{Introduction}

The genus Arundinella Raddi (1823) (Poales: Poaceae) is with about 55 species, having distribution in the tropical regions of the world, mainly in Asia (Clayton and Renvoize, 1986). Watson and Dallwitz (1992 onwards: http://delta-intkey.com/grass/www/arundine.htm) also accounted 55 species for the genus. Sun and Phillips (2006) estimated the present approximate number of species to be 60. As per Clayton et al. (2006 onwards: http://www.kew.org/data/ grasses-db.html) there are 68 species of Arundinella. The genus is represented by 21 species in India, of which 11 are found in Kerala (Hooker, 1896; Fischer, 1934; Bor, 1960; Sreekumar and Nair, 1991; Shaju and Mohanan, 2004; Kabeer and Nair, 2009).

During a recent floristic exploration in the foot hills of Brahmagiri, Wayanad district, Kerala, India some interesting specimens belonging to the genus Arundinella Raddi were collected. Critical study and analysis revealed that it is distinct from the hitherto known taxa of the genus and is described here as a new species Arundinella thirunelliensis.

Arundinella thirunelliensis Sunil, Ratheesh \& Sivadasan, sp. nov.

(Figs 1 \& 2).

Diagnosis: Arundinella thirunelliensis is similar to A. nepalensis Trin., but differs in being a rheophyte having large culms, glabrous culm nodes, leaf sheath and peduncles, effuse panicles with highly branched drooping branches, large, 3-nerved, deeply bifid smooth lemma with short twisted awn-column, and lower glume distinctly shorter than the lower lemma.

Type: India, Kerala: Wayanad District, Thirunelli, Kalindi river bed, 900 m, 8 Dec 2012, Sunil \& Ratheesh Narayanan 4854 (Holotype: CAL!; Isotypes: MH!).

Paratypes: India, Kerala: Wayanad District, Thirunelli, Kalindi, 12 Jan 2014, Sunil, Ratheesh Narayanan \& Prajeesh 1872 (CABC-MSSRF Herbarium!, Wayanad).

${ }^{1}$ Department of Botany, Payyanur College, Edat P.O., Payyanur, Kannur-670 327, Kerala, India

${ }^{2}$ M. S. Swaminathan Research Foundation, Puthoorvayal P.O., Kalpetta, Wayanad-673 121, Kerala, India

${ }^{3}$ Department of Botany \& Microbiology, College of Science, King Saud University, P.O. Box 2455, Riyadh11451, Kingdom of Saudi Arabia

${ }^{4}$ Corresponding author: E-mail: drmsivadasan@gmail.com 
Tufted, perennial rheophytes; clumps up to $60 \mathrm{~cm}$ wide; roots wiry. Culms $80-200 \mathrm{~cm}$ high, 3$5 \mathrm{~mm}$ across; nodes glabrous. Leaves: sheath up to $27 \mathrm{~cm}$ long, glabrous, ribbed; ligule a narrow rim with c. $4 \mathrm{~mm}$ long fimbriate hairs at apex and back; blade linear or linear-lanceolate, flat, stiff, $18-42 \times 0.4-1.0 \mathrm{~cm}$, base rounded, margin scaberulous or smooth, acuminate at apex, glabrous or upper surface with few scattered hairs. Inflorescence terminal panicles, $16-42 \mathrm{~cm}$ long, $7-20 \mathrm{~cm}$ wide, pyramidal; branches lax to effuse, alternate, spreading, lowermost up to $25 \mathrm{~cm}$ long; rachis

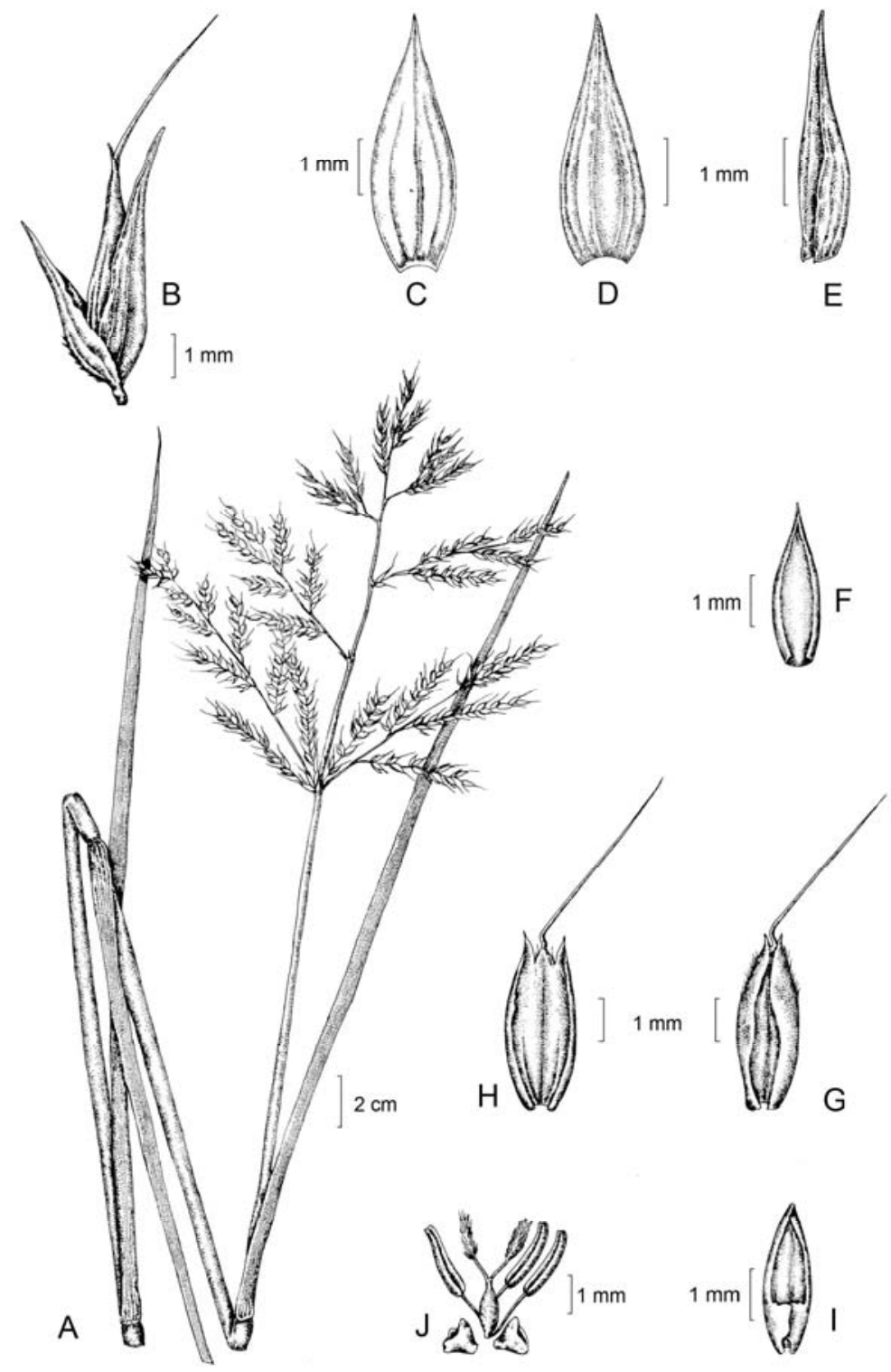

Fig. 1. Arundinella thirunelliensis Sunil, Ratheesh \& Sivadasan, sp. nov. A. Habit; B. Spikelet; C. Lower glume; D. Upper glume; E. Lower lemma; F. Lower palea; G. Upper lemma; H. Upper lemma - spread open; I. Upper palea; J. Lodicules, stamens and pistil. 

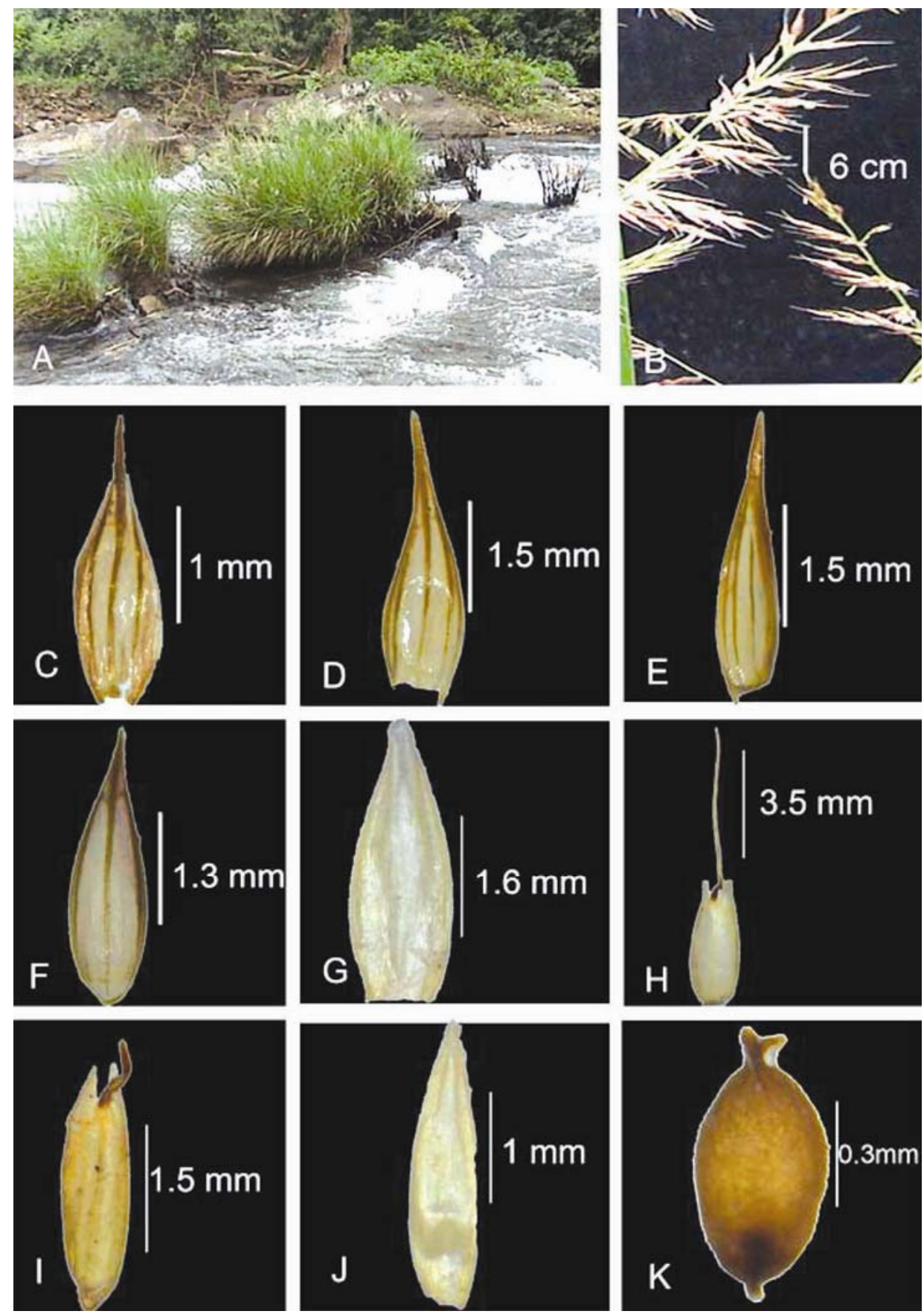

Fig. 2. Arundinella thirunelliensis Sunil, Ratheesh \& Sivadasan, sp. nov. A. Habitat; B. A portion of inflorescence; C. Lower glume; D. Upper glume; E. Lower lemma - ventral view; F. Lower lemma dorsal view; G. Lower palea; H. Upper lemma; I. Upper lemma showing bifid apex and twisted column; J. Upper palea; K. Caryopsis. 
angular, scaberulous. Spikelets elliptic-lanceolate, $4.0-4.5 \mathrm{~mm}$ long, pale to dark purple; pedicels 0.5-4.0 mm long, angular, scabrous. Lower glume ovate-lanceolate, $3.0-3.5 \times 1.0-1.5 \mathrm{~mm}$, acute to acuminate at apex, 3 or 5-nerved, scabrid on mid-nerve, pale purple with green nerves, chartaceous. Upper glume ovate-lanceolate, 4.0-4.5 $\times 1.0-1.5 \mathrm{~mm}$, acuminate at apex, margin hyaline, 5 or 7-nerved, pale purple with green nerves, chartaceous. Lower floret male or neuter. Upper floret bisexual. Callus glabrous or sparsely hairy. Lower lemma ovate-lanceolate, 3.5-4.0 $\times$ 1.2-1.5 mm, margin hyaline and ciliate towards apex, apex acute, very rarely with an up to $2 \mathrm{~mm}$ long awn, chartaceous, 3 or 5-nerved, green. Lower palea lanceolate to oblong-elliptic, 3.0-3.5 $\times$ 0.5-1.0 mm, acute at apex, 2-keeled, 2-nerved, membranous, hyaline. Upper lemma ovate or ovate-oblong, 2.5-3.0 $\times 1.0-1.3 \mathrm{~mm}$, margin involute, apex 2-lobed, awned from the sinus, subchartaceous, hyaline, 3-nerved, puberulous, whitish in fruits, smooth; lobes c. $0.5 \mathrm{~mm}$ long, ciliate along margin, acute or obtuse at apex; awn 4.0-4.5 mm long, geniculate with a chestnut-coloured, flat, twisted, 0.5-1.0 mm long column. Upper palea ovate-lanceolate, 2.5-3.0 $\times$ 0.7-1.0 mm, ciliate along margin, acute at apex, hyaline, membranous, 2-keeled, 2-nerved. Lodicules 2, triangular, c. $0.3 \mathrm{~mm}$ long, hyaline, apex irregularly lobed. Stamens 3, anthers $1.0-1.5 \mathrm{~mm}$ long, oblong, yellowish-brown. Ovary ovoid, 0.3-0.5 mm long; styles 2, c. $1 \mathrm{~mm}$ long; stigma c. $1 \mathrm{~mm}$ long, feathery, purple. Caryopsis ellipsoid, 1.0-1.2 $\times$ 0.5-0.6 mm, light brown.

Phenology: Flowering and fruiting occurs during October to February.

Etymology: The specific epithet denotes the type locality - Thirunelli in Wayanad district, which is one of the floristically rich regions on southern Western Ghats.

Ecology and distribution: Arundinella thirunelliensis was collected from a perennial stream bed. The new species has a distribution restricted to perennial stream beds that are occasionally subjected to flash floods. The plants are often associated with Homonoia riparia Lour., Rotula aquatica Lour., Cyperus sp., Equisetum sp., etc.

Comparison of characters of Arundinella thirunelliensis with A. nepalensis is provided in Table 1.

Table 1. Comparison of characters of Arundinella thirunelliensis with A. nepalensis.

\begin{tabular}{|c|c|c|}
\hline Characters & Arundinella thirunelliensis sp. nov. & Arundinella nepalensis \\
\hline Habit & Rheophytic grass & Terrestrial grass \\
\hline Culm node & Glabrous & Pubescent \\
\hline Leaf sheath & Glabrous & Glabrous or tuberculate hairy \\
\hline Peduncle & Glabrous below panicle & Pubescent below panicle \\
\hline Panicle & $\begin{array}{l}\text { Effuse, highly branched, branches alternate } \\
\text { and drooping }\end{array}$ & $\begin{array}{l}\text { Densely spiculate, branches simple and } \\
\text { sub-verticillate, secund }\end{array}$ \\
\hline Lower glume & Distinctly shorter than the lower lemma & About as long as the lower lemma \\
\hline Upper lemma & $\begin{array}{l}\text { 2.5-3.0 mm long, smooth, apex deeply } 2- \\
\text { lobed; lobes c. } 0.5 \mathrm{~mm} \text { long, acute or obtuse }\end{array}$ & $\begin{array}{l}\text { 1.0-1.5 mm long, granulose, apex } \\
\text { emarginate or shallowly 2-lobed; lobes c. } \\
0.05 \mathrm{~mm} \text { long, obtuse }\end{array}$ \\
\hline Awn & Column of awn $0.5-1.0 \mathrm{~mm}$ long when dry & Column of awn 2.2-3.2 $\mathrm{mm}$ long when dry \\
\hline
\end{tabular}

\section{Acknowledgements}

The authors are grateful to Dr. J. F. Veldkamp, Leiden, for a critical review of the manuscript. The encouragement provided by the Manager and Head of the Department of Botany, Sree Narayana Mangalam College, Maliankara, the Manager and Head of the Department of Botany, Payyanur College, Payyanur, and the Director, Community Agrobiodiversity Centre, M. S. 
Swaminathan Research Foundation, Wayanad are gratefully acknowledged. The last two authors thankfully acknowledge the encouragements and support extended by the Deanship of Scientific Research, King Saud University, through the research group project No. RGP-VPP-135. Sincere thanks are expressed towards Mr. Jayesh P. Joseph for the illustration and towards Mr. T. S. Rajeev, Dr. Sanal Kumar and Dr. Baiju, Department of Botany, S. N. M. College, Maliankara, Ernakulam for various help.

\section{References}

Bor, N.L. 1960. Arundinella. In: The Grasses of Burma, Ceylon, India and Pakistan. Pergamon Press, Oxford, pp. 417-428

Clayton, W.D. and Renvoize, S.A. 1986. Genera Graminum: Grasses of the World. Kew Bull. Additional Ser. 13: 1-389.

Clayton, W.D., Vorontsova, M.S., Harman, K.T. and Williamson, H. 2006 (onwards). GrassBase - The Online World Grass Flora. http://www.kew.org/data/grasses-db.html. Accessed on 17 April 2014.

Fischer, C.E.C. 1934. Arundinella. In: Gamble, J.S., Flora of the Presidency of Madras. Adlard \& Sons Ltd., London, pp. 1798-1802.

Hooker, J.D. 1896. Arundinella. In: Hooker, J.D., The Flora of British India, Vol. 7. L. Reeve \& Co. Ltd., London, pp. 68-77.

Kabeer, K.A.A. and Nair, V.J. 2009. Arundinella Raddi. In: Flora of Tamil Nadu - Grasses. Botanical Survey of India, Kolkatta, pp. 334-344.

Raddi, G. 1823. Agrostographia brasiliensis. Bertini, Lucca, 58 pp.

Shaju, T. and Mohanan, N. 2004. A new species of Arundinella Raddi (Poaceae) from Kerala, India. Rheedea 14: 47-50.

Sreekumar, P.V. and Nair, V.J. 1991. Arundinella Raddi. In: Flora of Kerala Grasses. Botanical Survey of India, Culcutta, pp. 332-346.

Sun, B. and Phillips, S.M. 2006. Arundinella. In: Wu, Z.-Y., Raven, P.H. and Hong, D.-Y. (Eds), Flora of China, Vol. 22. Science Press, Beijing. Peoples Republic of China and Missouri Botanical Garden Press, St. Louis, Missouri, USA, pp. 563-570.

Watson, L. and Dallwitz, M.J. 1992 onwards. The grass genera of the world: descriptions, illustrations, identification, and information retrieval; including synonyms, morphology, anatomy, physiology, phytochemistry, cytology, classification, pathogens, world and local distribution, and references. Version: 5th February 2014. http://delta-intkey.com/grass/www/arundine.htm. Accessed on 17 April 2014. 